\title{
Family therapeutic alliance and the prevention of re- lapse in collectivist Malay community in Malaysia
}

\author{
Zall Kepli Md Rejab ${ }^{I}$, Mahmood Nazar Mohamed ${ }^{l}$. \\ ${ }^{I}$ Cyberjaya University College of Medical Sciences, (CUCMS), Cyberjaya, \\ Malaysia.
}

Correspondence email: zallkepli@cybermed.edu.my

\begin{abstract}
Being a drug addict has a high probability of alienation, even if one belongs to a strong inter-dependent family. Culturally, it is simply that he had deviated from his family's piously-held values and norms. By capitalising on the idea of therapeutic alliance, the researchers identified a strong but slightly different form of therapeutic alliance which is a core value flourishing naturally in the Malay collectivist culture. Working on this collectivist family therapeutic alliance has enhanced effective communication and co-operation between the Recovering Addict (RA) and their family members which resulted in RA's capability to stay drug free. In this study, four RAs and 35 members of their family were put together to form four research groups. Open orientation group is adopted to suit the unpredictable group member's attendance during the four months' period of treatment. For the purpose of collecting data, the researchers used three sets of inventory called Establishing and Maintaining Therapeutic Alliance Inventory or EMTAI.1, EMTAI.2 and EMTAI.3, partly based on a modified version of Working Alliance Inventory (WAI) format. The results from pre and post tests showed that there is strong readiness among the subjects to establish and to maintain a therapeutic alliance. The follow up test, conducted two years after the last research group received treatment, showed that three out of four RAs successfully 'kicked the habit' and are living drug free lives.
\end{abstract}




$$
\text { زالت كابلي محمد رجالف العلاجي العائلي و الوقاية من الإنتكاسة في مجتمع الملايو المشاعي بماليزيا }
$$

عندما يكون الفرد مدمنا للمخدرات فإن عزلته تصبح أمر ا ممكنا حتى لو كان ينتمي إلى مجتمعا مشاعيا يتميز

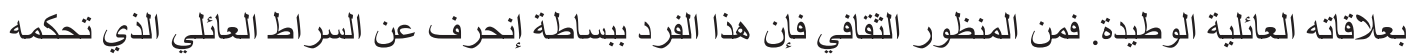

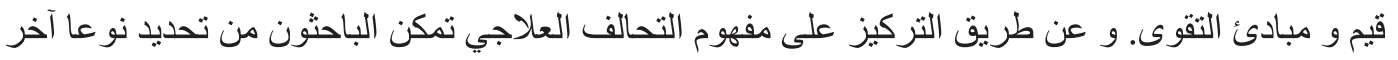

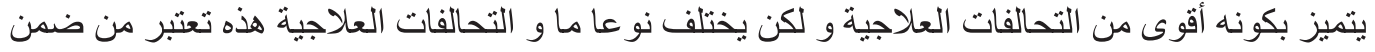

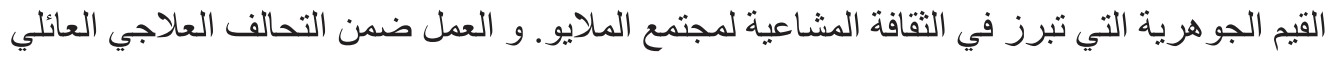

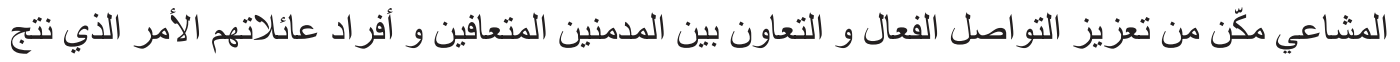
عنه محافظةالآخرين على أجسامهم خالية من المخدر ات. و في هذئ هذه الدر اسة تم جمع 4 مدمنين متعافين و 35

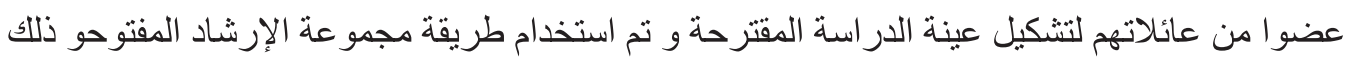

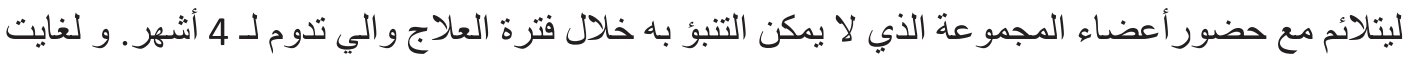

تتعلق بجمع البيانات، قام الباحثون 3 أنواع من عمليات الجرد تدعى الإنشاء و المحافظة على لاعلى عملية جرد

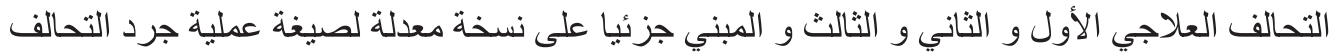

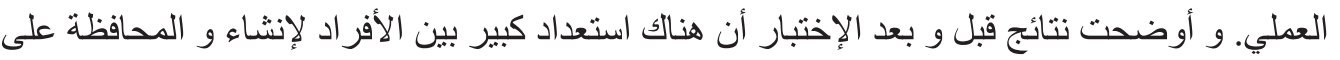

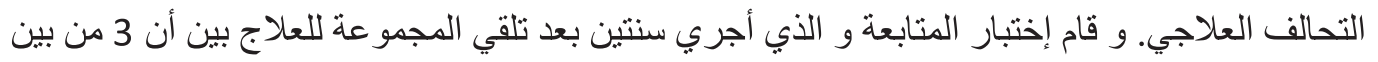

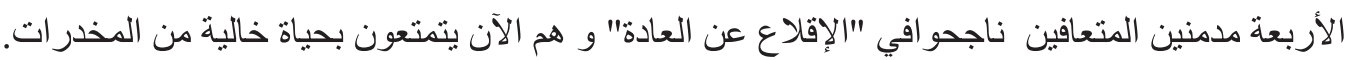

Keywords: Family therapeutic alliance, Recovering addict, Establishing and maintaining therapeutic alliance inventory, Working alliance inventory

\section{Introduction}

In a traditional Malay collectivist community, a person who is addicted to drugs is labelled as deviating against his or her family values and norms. To return to the family circle, one has to go through a long process to prove to the family that he repents and is committed to a new drug-free life. This is largely due to the traditional role played by their parents and families apart from the guilt experienced by the addict himself. For the family, giving in to a member of the family who is against the family values may be seen as encouraging the addict to continuously use drugs and repeating other unbecoming drug-related behaviours of which punishable sins are observed from their religious perspective. On the other hand, for the addict to return to the circle of his family of origin for a reunion, after the 'shameful' and 
heart breaking experiences inflicted upon his or her family, is a courageous act and a challenge to him and his family. In the light of such a situation, the need for a psycho-socio/ cultural friendly intervention is appropriate.

There are many collectivist Malay old idioms such as, "Sebusuk-busuk daging, dibasuh, dimakan juga"(translates as, "No matter how bad the meat stinks, we clean and still we eat") and "Setinggi-tinggi terbang bangau, akhirnya hinggap di belakang kerbau," (translates as, "No matter how high a stock flies, it is the buffalo's back he eventually sits on") These two idioms reflect important values of unconditional positive regard and home coming. The first idiom means, no matter how bad a blood brother or a sister is, should he or she repents, the person should be accepted into the family. The latter means, no matter how far, how long or on what reasons one left, eventually he will return home. Combining both idioms witnesses a situation where members of the conflicting parties are culturally encouraged to get together and to revive their familial relationship or "silaturahim", though there are other undefined cultural drawbacks. Exploring these values may help the researchers to get closer to the heart of the problem faced by RA and his family members in preventing relapse in the Malay collectivist community.

The most challenging task of this research project is to convince both RA and his family members to get together in an intervention group, putting their conflicts aside, and cordially work towards accomplishing a set goal of preventing RA's relapse. The success of the group depends much on their readiness to establish and maintain the family therapeutic alliance among them.

\section{Therapeutic alliance vs. Collectivist family therapeutic alliance}

Rogers ${ }^{1}$ defined therapeutic alliance as, ". . . the degree to which the client and therapist care about one another and agree on the goals and tasks of therapy". The kind of caring is at a high level and strong enough to ignore self-interest in helping one another toward achieving the desired goals. H.H. Strupp $^{3}$ said the degree of relationship that qualifies for therapeutic alliance is the one that "communicates commitment, care, interest, respect, and concern for the patient."

In the collective Malay community, probably as the most collectivist society in the East, a slightly different form of therapeutic alliance or family therapeutic alliance has always been the foundation of the family unity. Collectivist values such as faithfulness, family identity and cooperation which relate to the concept of familial self ${ }^{4,5}$, function close to qualities underlying therapeutic alliance mentioned by both Rogers ${ }^{1}$ and Strupp ${ }^{3}$. But as the degree of relationship in the family therapeutic alliance occurs at family level, it is assumed that the alliance created is stronger than the former alliance. 
Malay cultural and religious beliefs are part of the enforcing or binding elements of their family therapeutic alliance. For example, there is a strong belief among the traditional collectivist Malays that it is upto the individual or the family to uphold the religious value of "silaturahim" or family relationships. And failure to do so is punishable in terms of their religious teaching. Hence, in order to uphold deep-rooted values and religious teachings of "silaturahim", one is willing to do as his utmost effort, even to the extent of "bergadai bergolok" (Malay proverb, literally translated as 'pawning one's last piece of big knife') which means 'giving out to the last-penny'.

Considering cultural and religious value of the Malays, collectivist family therapeutic alliance or family therapeutic alliance is defined as "The nature of relationship that is tangled by love and concern for blood brothers/sisters and also by responsibility to balance family homeostasis. " It differs from the therapeutic alliance ${ }^{1}$ mainly in terms of its membership, values and the nature of the relationship.

\section{Objectives}

Therapeutic alliance has been widely recognised as a basis to therapeutic relation. ${ }^{5}$ For more than thirty years researches showed that quality therapeutic alliance "is a modest yet robust predictor of treatment outcome in individual psycho-therapy with adults" $7,8,9$ For older clients, therapeutic alliance measured at the early treatment stage showed a better indicator than the results measured at middle age. ${ }^{8,10}$ Researchers also found that the alliances between therapists and clients and therapists with clients families show encouraging results. ${ }^{11}$ In drug addiction treatment, family involvement forms a vital role in counseling. ${ }^{12}$ Family members have the influence of motivating drug addicts to stop taking drugs or prevent them from involving in dangerous activities. ${ }^{13}$ This has been a strong indication that where family forms a significant entity as in the collectivist society, alliance between family members is a potential element to be used in psycho-therapy.

In 1984, a research found that prisoners charged under the Drug Act 234, Malaysian Dangerous Drug Act (1952, amended 1980), ${ }^{14}$ confessed that the issue closest to their heart and most disturbing was when they thought of the days they would be released from prison and whether or not they would be accepted by their families. ${ }^{15}$ Again after 20 years, in 2004, the same question was asked from the prisoners in two prisons and one rehabilitation centre (a Therapeutic Community), the answers were the same. ${ }^{15}$ Another research finding showed that $94.5 \%$ residents of a Malaysian Anti-Drug Agency Rehabilitation Centre in Sabah chose to go home to their family once they completed their programme. ${ }^{16}$ 
The objectives of this study are to answer research questions such as:

I. Whether or not the Malay collectivist RAs and their families are willing to go through a therapeutic alliance-based group treatment together, in spite of their continuous strenuous relationship

II. As the treatment meant to empower the family, does the family therapeutic alliance last through a critical period of two years?

III. Is the therapeutic alliance-based empowered family, able to help the RA in preventing relapse?

IV. How impossible is a cultural/religious friendly family therapeutic alliance-based approach, as used in this study, to the clients of collectivist Malay subjects?

Figure 1 shows the path commonly travelled by the Malay drug addicts who walk out on his family's main cultures to embrace a sub-culture. When he gains sobriety after serving his time in prison or in a compulsory drug rehabilitation centre, he eventually races home, hoping to find shelter under the care of his family. Though most of the time, this 'stay in' with the family occurs only for a while, before he decides to return to the old trail of addiction, this is the point where his motivation to cooperate with the family to prevent relapse is high. Empowered and skilled family members would have the opportunity to take the advantage of this short stay of RA at their family home, to form a family therapeutic alliance and to foster changes in him.

Figure 1. Malay Recovering Addict Homecoming Circle

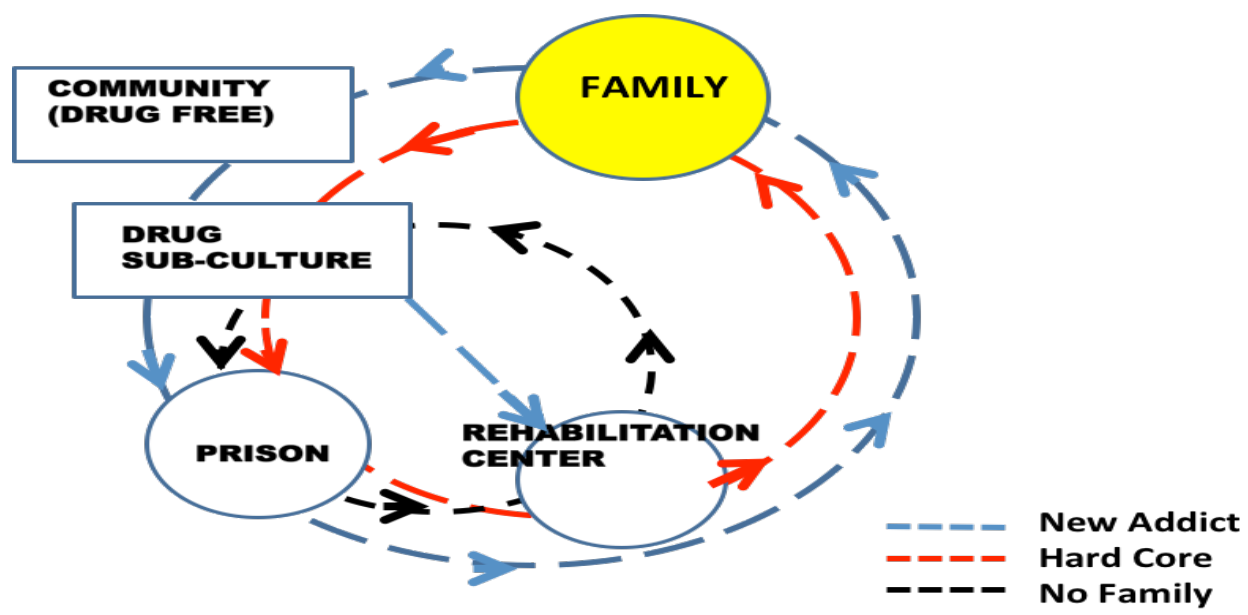

Zall MR \& Mahmood NM 2013 
Systematic, collectivist, multicultural and social learning theories are used in explaining the framework of research. Social learning theories reveal that drug addiction is a socially learned behaviour and can certainly be unlearned. Family approach with a multicultural approach is adopted to enable the family see things from RA's perspective, in order to have a deeper understanding of the issues around their RA.

The concept of familial-self strongly supports the Malay cultural and religious teachings in which priority is given to family over individual needs. This in turn helps to increase the bargaining power for a therapist to encourage re-establishment of family therapeutic alliance for both RA and his family. Once the subjects enter the alliance, the values of faithfulness, family identity and "silaturrahim" are put to their best test to create feelings of closeness and being loved, which makes him give up drug abuse. This in turn brings satisfaction to family members to reunite i.e. to be able to adhere to the religious teaching of "silaturrahim" and a chance to balance family homeostasis. The RA would also culturally free himself from the sins of being "durhaka" or infidelity to his family especially his parents. In the Malay collectivist community, a drug-free life is a life that is free from cultural and religious sanctions.

\section{Methodology}

This research uses a mixed-method with field experiment longitudinal design. A purposive-snowball sampling was conducted to select samples for the research. A briefing on the research project was given to group 37 final phase residents of one of the Malaysian Government's drug rehabilitation programmes in Kuala Lumpur. Four out of seven residents who volunteered involved their families and were selected for this research project.

\section{Table 1. Research Groups}

\begin{tabular}{|l|l|l|l|l|}
\multicolumn{1}{|c|}{ Families' Labels } & \multicolumn{1}{c|}{ Age } & \multicolumn{1}{c|}{ Male } & \multicolumn{1}{c|}{ Female } & \multicolumn{1}{c|}{ Total } \\
\hline Small Family & $21-50$ years & 2 & 3 & 5 \\
\hline Large Family & $12-48$ years & 4 & 6 & 10 \\
\hline Remarried Family & $30-53$ years & 5 & 2 & 7 \\
\hline Extended Family & $27-61$ years & 8 & 5 & 13 \\
\hline & & 19 & 16 & 35 \\
\hline
\end{tabular}

Zall MR. 2013 
Table 1 shows a number of groups/ families and members of each individual group i.e. ranging from five to 13 members. Three of the groups are nuclear families while the fourth is extended which showed the participation of an uncle, cousins and brothers /sisters in law.

Pre and post-tests were conducted using a set of questionnaires (EMTAI.1, EMTAI.2 and EMTAI.3) before and after the groups went through eight sessions of a specially created Collective Family Therapy (CFT). The follow up test was conducted two years after all groups completed their treatment sessions.

\section{Research Instruments}

A set of instruments used in this research called Establishing and Maintaining Therapeutic Alliance Inventory (EMTAI) was constructed partly based on a modified version of Working Alliance Inventory (WAI) format. ${ }^{2}$ EMTAI differs from a modified version of WAI in many ways i.e. number in inventory sections, its sub-scales used and of course the items. There are only two sections in EMTAI (Client Section and Family Section) whereas WAI consists of three sections. As EMTAI focuses on collectivist clients, it uses 'faithfulness', 'family identity' and 'perception of the treatment approach or family alliance as its sub-scales. Faithfulness and family identity domains are widely used to measure collectivist trait of interdependent and familial-self. ${ }^{5}$ Perception towards treatment and therapist approach is an important indicator for measuring individual's tendency to get professional help. ${ }^{20}$

The Cronbach Alpha value for the first 12 items of the two sections EMTAI.1 and EMTAI.2 namely the Family Section and the Client Section levels of reliability are 0.76 and $0.95 ; 0.88$ and 0.98 respectively, whereas the follow up on EMTAI.3 level of reliability is 0.89 (Family Section) and 0.9 (Client Section).

\section{The Treatment Module - Collective Family Therapy (CFT)}

Based on working experience with Malay clients in Malaysian Prisons for more than 30 years, researchers introduced an integrated multicultural family therapeutic alliance-based CFT to treat its subjects. Theoretically, CFT is an integration of the structure, social constructionism, adlerian and multicultural theories with underlying Malay collectivist, cultural and religious values. The main aim of CFT is to help RAs and family members (co-dependents) to empower their family. Steps are taken to initially redefine certain traditional Malay values that form stumbling blocks to effective communication, and also by collaborating with values that are commonly embedded in psycho- 
therapy and counselling such as levelling, openness, feedback and confrontation. The long term snowball effect of the therapy is observed in terms of family capability to maintain the alliance through the two year critical period and its effect on the ultimate goal of helping their RAs prevent relapse.

For the quantitative data, descriptive analysis is used particularly using percentage, table and also charts to explain data collected during the pre, post and follow up tests. This is so, due to the small sample of research subjects, and open group orientation that allows family members to attend the treatment sessions based on their free time. On the other hand, qualitative data analysis is used to analyse the data collected through various activities such as observation of the therapy process, structured and unstructured interviews, telephone conversations and short massage system. The accessibility of data from numerous resources also enables the researcher to use triangulation method to explain the research conclusion.

\section{Results}

Table 2 compares the scores of the highest level of the five-point Likert scale (EMTAI.1, EMTAI.2 and EMTAI.3) collected from the pre, post and follow up tests respectively, to reach the conclusions.

Table 2. Compared Scores: EMTAI.1, EMTAI.2 \& EMTAI.3

\begin{tabular}{|l|l|l|l|}
\hline & Faithfulness & Family Identity & Treatment Approach \\
\hline EMTAI.1 & $52 \%$ & $66.11 \%$ & $62.75 \%$ \\
\hline EMTAI.2 & $73 \%$, & $75.63 \%$ & $67.55 \%$. \\
\hline EMTAI.3 & $91.67 \%$ & $80.56 \%$ & $79.17 \%$ \\
\hline
\end{tabular}

Zall MR. 2013

Family identity gets the highest scores of $66.11 \%$ and $75.6 \%$ respectively. These indicate that family identity is the predictor for readiness to establish and to continue the family therapeutic alliance (after RA complets residential drug programme). On the other hand, to be able to really stick to the alliance for a long time, a stronger value of faithfulness toward one's family is essential. Follow up test shows that faithfulness scores $91.8 \%$ and is the indicator for maintaining family therapeutic alliance over a long period or in the case of this study, an interval of two years.

Data collected from various sources are used to construct a triangulation, as demonstrated in Table 3 below, to explain the research conclusion. 
Table 3. Triangulation Evidence

1. Subjects successfully forming and maintaining their therapeutic alliance through treatment and interval period of two years.

5. Data established in the form of Metric Resources and Data Extract (Fairclough, 1995) show changes in various aspects of relationships.

3. All IKMP.1 items scores showed $100 \%$ support to establish therapeutic alliance.

4. All IKMP.2 items scores showed $100 \%$ support to continue therapeutic alliance.

5. All IKMP.3 items scores show 100\% support to maintain therapeutic alliance.

1. The subjects were $100 \%$ ready to establish and maintain family therapeutic alliance.

2. The therapeutic alliance-empowered family has a $75 \%$ chance to survive through the 2- year critical period.

3. Family therapeutic alliance capable of helping RAs to stay drug free.

6. Three out of four groups/families (subjects) managed to maintain therapeutic alliance throughout the 2-year critical period.

7. Three out of four RAs managed to stay drug free lives during and after the two-year critical period.

Citation: Zall MR. Relapse Prevention and Therapeutic Alliance among Collectivist Malay Recovering Addicts and Their Family. [PhD Thesis] University Utara Malaysia. 2013. Table 3 Triangulation Evidence. p. 216

Two important findings collected from the follow-up test are:

i. Three out of four families successfully maintained therapeutic alliances over the two years of research interval period.

ii. All three RAs from the survived empowered families saw that their RAs are able to stay drug free. The family that failed to maintain the therapeutic alliance among its family members, due to the unsettled broken home related issues, saw their RA returning to drug use.

As for CFT, the above results are supportive of its feasibility as a treatment approach for research subjects (collectivist Malay families and their RAs). Item number 14 of the EMTAI.2, conducted during post-test, "I agree to 
recommend for more residents and their families to be treated with this approach (CFT)," showed a 100\% positive response (Agree, 20\%; Very Much Agree, $80 \%)$.

\section{Discussion}

Returning home is a common occurrence among the Malays as well many other Eastern collectivist communities. This, shown as being the theoretical framework of this research, is also common among the addicts who had completed the time in prisons or compulsory rehabilitation centres is high despite their worry of not being accepted by their families. ${ }^{15,16}$ Generally they recognise that family is a very significant entity. For an addict, going home also means "...balik ke pangkal jalan" (Malay idiom) or going back to where you start (as a non-addict) when you are lost at the end of the road. This old saying is considered as an advice or a call from the family to its members to stop being unruly.

A related research conducted among the addict's family members and friends shows that there is a significant social support for the RAs to start a drug free life. ${ }^{21}$ Since this support explicitly failed to echo by the families to the addicts, for the lack of open communication between them, the addicts may view this as family's lack of effort to help them be free from drug addiction. Additionally, guilt and the uncertainty of a chance to be accepted by their family, based on their past experience of rejection, instead breed more alienation between both parties. On the other hand, family members who experience several unsuccessful attempts in helping their loved ones may hesitate to openly announce their support for fear of more failures. Both parties as it is, seem to have reasons of their own to refrain from initiating effective communication.

As there are positive inclinations for both parties to re-establish relationship between them, steps to initially educate the family members, helping them to understand the need to get to the bottom of their issues and to revive their hope for a balanced family homeostasis, as shown by the research finding, is high. At this point they need a good persuasion or reasons for doing it or even a common goal. The next thing is an appropriate strategy to address the issues around the RA and his family. Consideration should also be given to the cultural values and religious beliefs of the family. This is where cultural/ religious friendly family therapeutic alliance-based therapy (CFT) is crucial firstly to encourage a full acceptance of the treatment strategy and to effectively mend the rift of communication between both parties.

The Malay cultural/religious teaching demands respect for the elders, especially one's parent. This in turn, helps the elderly members or one's parent 
to function as a leader in his family much easier when the power is made available and strongly supported by the cultural and religious teachings. For example, as "silaturahim" is in their blood and their minds, establishing a proposed family therapeutic alliance to this family is just like helping them to get together again as they used to, but with a new and better perspective of living together. This is a gateway to overcome various issues among the family which is most welcomed as in the case of this study.

The cultural and religious demands are also reflected during the running of eight sessions of CFT, beginning with the $100 \%$ response to the call for establishing, completing the entire treatment, continuously adapting to the norms and values practiced in the group, and maintaining the alliance throughout the interval of the two year period. Although family decisions sometimes is not truly a collective decision, but a parent's decision, the inclination to abide to this decision is genuinely resulted out of faithfulness, family identity and "silaturrahim". Readiness to establish, to continue and to maintain therapeutic alliance showed that subjects in this research demonstrate the support given to the concept of familial-self. It is an imperative act in a collectivist Malay community as it reflects on individual's compliance to give priority to their families over their own interests. For example, in this research, to be able to participate in the eight sessions of all members' family-of-origin therapy group, a member is required to leave their own family on weekends for a period of three to four months, abandon other social obligations, and travel over hundreds of kilometres. In a situation like this, one may not hesitate to appreciate the kind of love the members have toward their family.

Therapeutic alliance ${ }^{1}$ in the form of family therapeutic alliance is much relevant to the Malays' interdependent way of life as it is a culturally and religiously supported concept. By integrating certain theories and strategies commonly found in the western originated counselling and psychotherapy, with these critical values of the Malay community, it has resulted in a friendlier CFT.

Alienation from one's family-of-origin or vice-versa can occur even in a close-knitted family such as the collectivist Malay family. This can be caused by the lack of effective communication which has been hindered by conflicting values such as the tendency to uphold 'silaturrahim' but refusing to have anything to do with a 'sinful person'. Therapeutic alliance in the form of family therapeutic alliance is a convinced way to reunite with the family, enhance communication by re-defining the conflicting values as well as injecting values common to the psychotherapy or family counselling. 


\section{References}

1. Rogers CR. The necessary and sufficient conditions of therapeutic personality change. Journal of Consulting Psychology, 1957;(21):95-103. Doi: http://dx.doi.org/10.1037/h0045357

2. Tracey TJ, Kokotovic AM. Factor structure of the Working Alliance Inventory. Psychological Assessment. 1989;(1):207-10.

Doi: http://dx.doi.org/10.1037/1040-3590.1.3.207

3. Strupp HH. The future of psychodynamic psychotherapy. In: Corey G. Theory and Practice of Group Counseling. Thomson, Brook/Cole; 2008;P160-65

4. Sinha D, Sinha M. Orientations to psychology: Asian and Western. In: Kao SR and Sinha D. (Eds). Asian Perspectives on Psychology. Princeton University Press; 1997;P68-69

5. Corey G. Theory and Practice of Group Counseling. Belmont: Thomson Brooks/Cole; 2008.

6. Yuki M. Intergroup Comparison Versus Intragroup Relationships: A Cross-Cultural Examination of Social Identity Theory in North American and East Asian Cultural Contexts. Social Psychology Quarterly. 2003;66(2):166-183.

Doi: http://dx.doi.org/10.2307/1519846

7. Horvath AO, Luborsky L. The role of the therapeutic alliance in psychotherapy. Journal of Consultant and Clinical Psychology. 1993;(61):561-73.

Doi: http://dx.doi.org/10.1037/0022-006X.61.4.561

8. Horvart AG, Seymond DB. Relationship between working alliance and outcome in psychotherapy: A meta-analysis. Journal of Counseling Psychology. 1991;(38):139-49.

9. Martin D J, Garske JP, Davis MK. Relation of the therapeutic alliance with outcome and other variables: A meta-analytic review. Journal of Consulting and Clinical Psychology. 2000;(68):438-50.

Doi: http://dx.doi.org/10.1037/0022-006X.68.3.438

10. Horvath AO. Research on the alliance. In: Horvath AO, LS. Greenberg (Eds.). The working alliance: Theory, research, and practice. New York, Wiley; 1994;P259-86. 
11. Shirk SR, Karver M. Prediction of treatment outcome from relationship variables in child and adolescent therapy. A meta-analytic review. Journal of Consulting and Clinical Psychology. 2003;(71):452-64.

Doi: http://dx.doi.org/10.1037/0022-006X.71.3.452

12. Steinberg ML, Epstein EE, McCrady BS, Hirsch LS. Sources of motivation in couple outpatient alcoholism treatment program. American Journal of Drug and Alcohol Abuse, 1977;(23):191-205.

13. Malaysian Dangerous Drug Act, 1952, amended 1980. Kuala Lumpur: Malaysian Government Publisher: 2008

14. Zall MR. Kaunseling Pra-Kepulihan, Laporan Ilmiah Program Sarjana Kaunseling, Universiti Kebangsaan Malaysia. In: Daftar Bidang Masalah Kepulihan (DBMK): Penilaian Program Pemulihan Dadah Dari Perpektif Penagih Separa-pulih. Proceeding National Drug Conference I, Universiti Malaysia Sabah. 2007 Nov 5-7. Sabah, Malaysia.

15. Zall MR, Amran A, Ismail M. Jarak hubungan kekeluargaan: Dari Persepsi Penagih Separa Pulih. Proceeding of the 6th Malaysian National Public Seminar. University Terangganu Malaysia. 2008 Aug 1617. Terangganu, Malaysia.

16. Triandis HC. Individualism and Collectivism. Colorado: Westview Press; 1995.

17. Heine SJ, Lehman DR, Markus HR, Kitayama S. Is there a universal need for positive self-regard? In: Mayer DG. Social Psychology. New York: Mc Graw-Hill; 2008;41-44.

18. Kim U. Asian collectivism: An indigenous perspective. In: Koa HRS, Sinha D. (Eds). Asian Perspective on Psychology. New Delhi: Sage; 1997;147-63.

19. Cusack J, Deane FP, Wilson CJ, Ciarrochi J. Who influence men to go therapy? Reports from men attending psychological services. International Journal for the Advancement of Counselling. 2004 Sept;26(3):271-83.

Doi: http://dx.doi.org/10.1023/B:ADCO.0000035530.44111.a8

20. Zall MR, Shuaib CD, Balan R, Joki PS. Hubungan Sokongan Sosial Dengan Kadar Relaps: Satu Kajian Multibudaya Di Sabah. Proceeding of SEAP Psychology Seminar, University Malaysia Sabah. 2009 July 9-11. Sabah, Malaysia. 